\title{
Eyes on the prize: transnational tobacco companies in China 1976-1997
}

\author{
Belinda O’Sullivan, Simon Chapman
}

\begin{abstract}
Internal tobacco industry documents relevant to China as published on www. tobaccoarchives.com located between 31 May and 1 August 1999 were searched. Documents describing the ambitions and conduct of transnational tobacco companies (TTCs) in China between 1976 and 1997 were located and reviewed in three sections: part A-early identification of market potential and attempts to enter the market, and improve trade and technology; part $\mathrm{B}$-marketing and promotion efforts; part $\mathrm{C}$-efforts to pre-empt legislation, control the smoking and health debate, and undermine the anti-tobacco lobby.

(Tobacco Control 2000;9:292-302)
\end{abstract}

Keywords: China; transnational tobacco companies; marketing

\section{Notes on methods}

The documents discussed in this paper were located from www.tobaccoarchives.com from the company sites of Philip Morris (PM), RJ Reynolds (RJR), Lorillard, Brown and Williamson $(\mathrm{B} \& \mathrm{~W})$, the Tobacco Institute Inc. and the Council for Tobacco Research, USA. They were found in searches undertaken between May 1 and August 31 1999. A purposive search using 54 search terms was undertaken using the simple and advanced searching functions on each site to identify documentation pertaining to China including references to the People's Republic of China (PRC), Hong Kong, Macau, and Taiwan. Documents were excluded that were illegible; in languages other than English; shipping documents; duplicates; newspaper articles; and other documents judged to have little interest to policy analysts in tobacco control.

Documents of relevance to the research aims

Department of Public Health and Community Medicine, University of Sydney, New South Wales, Australia

B O'Sullivan

S Chapman

Correspondence to: Simon Chapman,

Department of Public Healt and Community Medicine, University of Sydney, Bldg A27, NSW 2006, Australia; simonc@health.usyd.edu.au

Received 25 November 1999 and in revised form 11 April 2000.

Accepted 20 April 2000 relevant documents will have been posted on the sites.

\section{Historical background}

The first words uttered by James B Duke (1865-1925), the tobacco tycoon who established the empire now known as British American Tobacco, on hearing of the invention of the cigarette machine, were "Bring me the atlas". When they brought it he turned over the pages. He stopped at the figure "Pop.: 430,000,000". "That," he said, "is where we are going to sell cigarettes." And "that" was China. ${ }^{1}$ By 1915 BAT had established a foundation for a "monopoly that seemed unshakeable". ${ }^{2}$ At the turn of the century the BAT advertising system "left no region of China untouched".

China's annual consumption of cigarettes rose from a negligible number in the 1890 s to about 100 billion in the early 1930s, a rise ascribed to the business practices of the cigarette industry. ${ }^{3}$ BAT was forced to leave China in 1952, after half a century in which its total profits there had amounted to more than US $\$ 380$ million. $^{2}$ As BAT departed, leaving behind an established cigarette smoking habit, it reportedly forecast "We will be back". And so they are.

The Chinese population is approximately 1.3 billion people, ${ }^{4}$ constituting $23 \%$ of the world's population. Some $63 \%$ of adult males and $4 \%$ of females smoke, with $75 \%$ of males starting before the age of $24 .^{5}$ Adult per capita consumption of tobacco increased from 890 to 1990 between 1965 and $1999 .{ }^{67}$ The smoking epidemic in China is now seeing some $50 \%$ of male smokers dying from smoking related disease, and causing around a third of all deaths in the 35-69 year age group. ${ }^{8}$

The government owned Tobacco Corporation (CNTC) dominates the Chinese cigarette market. However, the idea of even a small share in such a huge market has long mesmerised the world's transnational tobacco companies (TTCs) Philip Morris (PM), RJ Reynolds (RJR), Lorillard and British American Tobacco (BAT), and its American subsidiary Brown \& Williamson (B\&W).

Accounts of the activities of TTCs in China have until recently been limited to the observations of tobacco control activists and the industry's own public reports in the trade and financial press. With the publication of millions of pages of tobacco industry documents on the internet in 1998, unprecedented prime source material became available that provides hitherto unreported insights into the 
involvement of TTCs in China. This paper aims to examine the involvement of the TTCs in China between 1976-1997.

Part A examines evidence about the TTC's hopes and plans for gaining entry to the Chinese market. It traces early interactions with the CNTC, action on trade, import licensing and taxation. It includes information on the development of joint ventures and the use of political pressure to lever China open to foreign competition.

Part B examines evidence about TTC efforts to advertise and promote their products in China, and how they sought to publicly argue (as in the West) that this advertising is only intended to secure market share from current smokers. It also details industry responses to marketing restrictions and the use of philanthropic activities and other tactics to counter claims against the industry.

Part C considers examples of TTC efforts to obfuscate the issue of tobacco caused disease from both active and passive smoking, as well as their appraisal of counteracting forces promoting tobacco control in China.

\section{Part A: China's potential and early pursuit of the Chinese market}

China was largely closed to foreign trade from around 1949 until 1979. However, the documents indicate that the Chinese were evidently collaborating with the TTCs over trade issues as early as 1977, after the Cultural Revolution (1975) and two years before foreign investment was formerly legalised in 1979. In 1977 two officials from the Commercial Office of China, visited PM's offices in Bern, Switzerland. A PM memo records the officials' "express[ing] again their readiness to promote trade between Philip Morris and China". ${ }^{9}$

The first reports of TTCs visiting China date from 1979. PM's William Campbell, executive vice president for PM Asia, reported to his colleague Helmut Wakeham: "I feel that commencing with our visit to Peking we have shown Philip Morris to be a first class organization of professionals that will truly benefit the Chinese in any trading relationship. I think this most recent visit has allowed the Chinese to really see what Philip Morris is all about and put us that much closer to establishing a meaningful business relationship."10 Approximately 10 joint ventures were signed with the CNTC in 1979 when China legalised foreign investment. ${ }^{11}$

As might be expected, the sheer immensity of the Chinese market for tobacco bedazzled the TTCs. Developing nations, and China in particular, were seen as essential to the companies' global ambitions and overall profitability. The young demographic profile of populations in the region presented particular interest. A PM marketing plan for 1981-85 noted that: "major markets such as Japan, the Philippines, Malaysia and Hong Kong all have over $50 \%$ of their populations below 35 years of age while the 20-35 age group constitutes the primary cigarette consumer group."12

Philip Morris were acutely aware that: "The Chinese cigarette market is already three times the size of the US market, and accounts for over $30 \%$ of the world's 5.4 trillion units. Since the total international segment amounts to less than $1 \%$ of this huge market, we have plenty of room for dramatic growth." ${ }^{13}$ A PM PRC marketing briefing stated: "The Chinese domestic tobacco industry is a major frontier for international tobacco companies." ${ }^{14}$ With the growth in spending power in developing nations PM estimated the potential for an "international quality cigarette" market in China of "between 55 and 70 billion units" in 1994, adding: "As China is making rapid economic progress at this time, especially in coastal areas, this potential market could exceed 100 billion units within ten years."13

In 1993 PM's Geoffrey Bible reassured colleagues at a plan presentation that "early development markets" like China were considered "critical for PM to sustain its growth into the next millennium and we are taking steps now to ensure our place in their future." ${ }^{15}$ Bible expressed his vision thus: "Put another way, 10 years ago, one out of every 16 cigarettes smoked outside the US was one of our brands. Today it is one out of 12 . In 10 years it will be one out of eight - with potential given the current US level of one out of two and a half." International sales by PM increased $80 \%$ between 1990 and 1998 whereas domestic US growth has been only $5 \% .^{16}$

Constrained by a lack of foreign exchange, around $1984^{17}$ the Chinese pursued joint ventures as a way to obtain technical assistance from the TTCs, ${ }^{18}$ shopping around the TTCs for various joint venture possibilities for specific technologies: "A delegation from CNTC and the Shanghai Factory plan to visit the US during the second week of May to see PM's DIET plant and RJR's G-13 facilities for comparison of the two processes. ${ }^{19}$ In 1985 RJR's Dr Cliff Mansfield reiterated the importance of the Asian market after the world tobacco exhibition and conference stating that the "CNT is willing to establish trade on two conditions: (1) transfer of technology with trade; (2) combination of import with export. Joint ventures are welcome."20

In 1985 the occurrence of "goodwill" gestures from PM to China served to indirectly improve tobacco quality. ${ }^{21}$ The PM International Business Plan 1989-1993 stated: "We will concentrate our efforts on fostering good relations with the ...(CNTC) ... through technical assistance projects, and will consider investing in a joint venture if CNTC is willing to pursue one." 22 Inter-office correspondence dated 1989 described a scheduled visit by the vice president of the CNTC, Jin Maoxian, to PM's New York Headquarters to give: "an overview of PM's participation in China (referencing Diet, Dragon and FML), and the introduction of the cooperative production idea." ${ }^{23}$

During these overtures, the CNTC sought to safeguard the golden prize of the Chinese cigarette market by restricting TTCs to fixed revenues in the joint venture arrangements. Total fixed capital of the PM-CNTC joint venture Shenzhen factory was limited to $\$ 14$ million. A frustrated PM source commented that: 
"Fourteen million dollars is clearly insufficient for a high tech factory or a level of technology likely to satisfy Chinese aspirations . . The project is a hazard in terms of: quality-timecost satisfaction of the Chinese and PM partners." ${ }^{18}$ Clearly mindful of their long range vision of the probable Chinese market "is it better to withdraw than to commit to a possible business failure and a loss of face. If, however, our long range goals in China are of significant importance, then surely the project must be properly funded, conceived and executed."18

TAXATION

The TTCs were also frustrated in their export attempts to China by tax barriers. Reducing taxation thus became vital to the TTCs' Chinese agenda while opportunities for internal production capabilities remained frozen. Efforts were made in 1992 to develop "an internal capability and expertise to address tax issues within the region." " In 1991 Clive Turner, managing director of the Asian Tobacco Council, recommended a review of taxation levels across the Asian region to show: "which countries were vulnerable to pressure to raise those levels - and therefore what tactics should be employed to maintain existing levels." 25

The TTCs aimed to promote the concept of a flat excise tax so as to reduce price differentials between imported and locally produced cigarettes. Burrell commented: "we prefer a tax adjustment that eliminates or substantially narrows the gap between monopoly and international brands" ${ }^{26}$ In 1985 , Clive Turner sought to demonstrate to Asian governments that taxation across the Asian region in general was "over the top, and needlessly punitive" 27 and that excessive taxation would "further reduce the taxable base" for governments leading to "a revenue reduction". ${ }^{28}$ They sought to "persuade them that, in order to optimise their revenue derived from the cigarette industry" that they should institute a "simple system, a flat excise tax based on per thousand cigarettes". ${ }^{28}$

The correct interplay of taxation and marketing capabilities was critical to maximising market penetration. In 1990 PM's John Dollisson stated: "We need to actively pursue the defence of the value of advertising-by ourselves and in coalitions. Without advertising, retail pricing becomes more important." ${ }^{29}$ Projecting options for maximising business capacity, a tax and marketing trade-off was discussed by Wendy Burrell of Philip Morris Asia in 1992: "if . . there is room to negotiate a tax gap narrowing and preserve some marketing freedoms (especially point of sale), that would be a satisfactory outcome."26

SMUGGLING

Throughout the protracted market penetration efforts, access to TTC brands was being achieved through significant levels of smuggling. In 1989 in the context of discussion over a contracting import sector, the suboptimal progress was considered a temporary setback by Bill Webb given that "the widespread importation of consumer goods outside official channels is allowing traders from Hong Kong to satisfy market demand for our products and preserve our business base." ${ }^{30}$ Black market trading was mentioned again in 1991: "Unofficial imports, competitively priced and available in local currency, will continue to compete with duty-paid imports in the Domestic sector." ${ }^{31}$ With "some $60 \%$ of all smuggles (sic) goods into China [being] cigarettes" rampant smuggling was highlighted as the cause of the Chinese government deciding to liberalise import rules and work to establish a wholesale cigarette market in 1992. ${ }^{32}$ Evidently smuggling-whether actively supported or passively condoned by the TTCs - proved to be a highly useful TTC weapon that precluded future trade restrictions.

In 1998, Jerry Liu of BAT was sentenced to jail for conspiring to accept $\mathrm{HK} \$ 23$ million in bribes and a corrupt $\mathrm{HK} \$ 10$ million loan from cigarette distributors in exchange for huge quantities of duty-free cigarettes to be smuggled onto the Chinese market. Mr Justice Wally Yeung Chun-kuen commented that such crime targeted youngsters by providing them with cheap black market cigarettes. ${ }^{33}$

IMPROVING TRADE CAPACITY

The TTCs actively pursued better trading capacity for their cigarettes in China. Activities included negotiating with the US Trade Office, establishing a United States Cigarette Exporter's Association (USCEA) incorporating domestic and Asian representation, and finally, lobbying of foreign and US friendly politicians and media executives. Letters to the US Trade Office frequently critiqued any proposed limitations on trade and defended cigarette exports. In 1990, PM's public relations company, Burson-Marsteller, recommended the creation of a Joint Enterprise for Trade (JET) organisation in an attempt to create a more effective voice on international tobacco issues.

In a global tobacco trade document from the USCEA, trade was dissociated from health policy, and premised on the legality of cigarettes, the demand for international quality cigarettes in developing countries, and by embracing notions of unfettered global free trade. A reference was made to former US Trade Representative Clayton Yeutter who suggested that: "trade policy, not morals or health policy, is the fundamental issue involved in the exportation of cigarettes." ${ }^{34}$ An example of the strategy framing the trade debate away from health was a 1990 document: "Huddleston [seemingly part of a contingent of elected officials appointed for Kennedy export hearings] was unflappable and did very well. He never got bogged down in discussions of health or advertising excesses. $\mathrm{He}$ successfully linked 301 cases with the need to allow for advertising (i.e. competition)." ${ }^{35}$ Other documents included statements like: "The USTR has respected legitimate, health related measures involving cigarettes and other commodities, but has challenged those that are 
phony (sic) and designed to afford protection to government monopolies."36

Documents were careful to frame TTC tobacco exports as simply meeting existing demand by smokers. In USCEA tobacco export policy documents PM insisted: "Essential to an understanding of United States cigarette exports is the fact that what is being exported is cigarettes, not smoking." ${ }^{37}$ RJR stated in another USCEA document on global tobacco trade: "In short, American manufacturers are trying to sell cigarettes to people who already smoke and who will continue to smoke whether or not American cigarettes are available." ${ }^{34}$ The USCEA framed arguments supporting trade, indicating there was no coercive marketing in the cigarette trade and appealing to the US government to see it as benign: "In trade negotiations, the United States has not insisted, or even requested, that other countries purchase American cigarettes. It should be noted, in any event, that governments do not use cigarettes-smokers do." ${ }^{37}$

In 1990 the JET commented on current Congressional efforts which threatened to preclude future government agency assistance for tobacco exports, arguing: "Without this assistance the industry would not have gained access to the cigarette markets in Japan, Taiwan and South Korea, or made any progress on access to the Thailand market. Lacking a strong, consistent advocate in government, US cigarette exporters have been painted as villains." ${ }^{38}$

Around 1993 with the advent of the Clinton administration and Mickey Kantor as Clinton's first Trade Representative, the USTR (United States Trade Relations) decreasingly placed cigarettes on the trade negotiating table. ${ }^{39} 40$ "Our principal political leverage in gaining access to markets in the region is the backing of US trade negotiators. But the Clinton administration has indicated it is not willing to campaign on behalf of the tobacco industry. This means our power base is weakening." ${ }^{41}$

The popularity of American cigarettes was assumed to be largely based on the fact that "American cigarettes are a competitively priced product of extremely high quality" ${ }^{34}$ and to support their claims "even anti-smoking advocates, such as Gregory Connolly, admit that foreign cigarette monopolies produce a darker, less flavourful cigarette than US brands." 34

In 1994, Bill Webb of PM mentioned the courting of the Chinese Minister of Foreign Trade and Economic Cooperation over export rights at a goodwill luncheon: "We hope to impress Minister Wu with our commitment to China . . .offering the best quality products, state-of-the-art technology and world class business expertise." ${ }^{42}$ Broad objectives were articulated in the briefing materials: "We do not view this as an appropriate time to discuss specific business problems we face. Rather, we want to establish cordial relations and express our enthusiasm for our business interests in China." ${ }^{2}$ Minister Wu was reminded that: "Philip Morris is a staunch supporter of free trade and is actively working to gain support for MFN [most favoured nation] status for China on a permanent and unconditional basis". Webb cited a letter recently written to President Clinton, and said that the TTCs had contacted "at least 20 members of Congress to underscore the importance of this issue." ${ }^{\prime 3}$

IMPACT OF TTCS ON CHINESE TOBACCO INDUSTRY Efforts were made to incorporate China into transnational tobacco circles as a collaborator. Dollisson of PM believed that trade effectiveness may be enhanced by meetings of trade associations and ongoing technological exchanges that may improve the capacity for the industry to influence national policies. ${ }^{44}$ In 1992, a special Chinese language section of the Tobacco Reporter was sent to some 450 CNTC senior officials and factory managers "to raise issues of general concern to the industry and help CNTC officials better understand the broader issues faced by the industry worldwide." ${ }^{24}$ PM decided to: "Encourage and assist China to take part in CORESTA. Being the largest tobacco producing country in the world, China should not only be interested in sitting on the board, but should actively participate in all basic functions through contributions in work groups, task forces, surveys, and in cooperative studies." ${ }^{45}$ CORESTA, a cooperative tobacco research network, started in 1955 with 24 members. By 1982 it had 140 members in 57 countries. ${ }^{46}$

The TTC involvement was inspiring to the Chinese tobacco industry which appeared to see it as a chance to develop higher quality blending, casing, and flavouring techniques needed for western style cigarettes, and learn transnational tobacco trade principles, as well as make international contacts. ${ }^{47}$ In 1990, cooperation with foreign specialists resulted in cigarettes of international flavours being produced by the CNTC. ${ }^{47}$ The CNTC stated: "We need to learn from our foreign friends the advanced and suitable science and technology as well as management experiences and we are also willing to take part in the competition and development of international markets." ${ }^{47}$ Domestic and international business opportunities were related to foreign friends by the CNTC at the same symposium: "the huge domestic market gives the tobacco industry the potential and possibility to pursue steady development . . there is still a big potential for further expansion in the Chinese tobacco market." 47 Further: "In recent years the Chinese tobacco export business has been growing. The Chinese tobacco has been exported to more than 20 countries and regions around the world. The country's cigarette export is expanding." ${ }^{\prime 7}$ Since TTC involvement in China, tobacco is increasingly consumed in the form of manufactured cigarettes $(87 \%){ }^{6}$

CHOOSING HONG KONG AS A MARKET BASE The TTCs debated several market expansion options pending the decentralisation of Chinese tobacco trade. Timely market entry to Hong Kong was imperative with the changing political powers over Hong Kong in 1997. 
Because of the monopoly's tight control over trade in China, Hong Kong was viewed as an accessible market base and observation point for TTCs wanting to penetrate China. A 1991 document People's Republic of China stated: "Local production seems to be the only means through which we can gain broad access to the total Chinese market. An additional consideration is that we need to establish a manufacturing base in China prior to the Hong Kong market's coming under the jurisdiction of CNTC Bejing (sic) in 1997." 31 By 1993, PRC market access was considered to be a matter of capitalising on opportunities that might arise with changes in government policy: "Under the tight control from the monopoly, it is very difficult to gain access to the PRC market. However, China is changing and the changes can be sudden and unpredictable . . .we must prepare ourselves to capitalise on any relaxation of rules and regulation." ${ }^{39}$

MANUFACTURING ARRANGEMENTS

With 10 years investment in equipping factories with modern technology between 1983 and 1993, seizing a significant portion of the PRC market through innovative manufacturing arrangements was on the agenda. In a 1993 document China Vision 2000+, various production arrangements were contemplated ranging from a joint venture cut tobacco factory with brand licensing, a wholly foreign owned licensed PM brand factory or direct licensing. " ${ }^{39}$ "Our recommendation is to lobby for a joint venture cut tobacco factory with a 10 billion units capacity as our first try ... we may have to settle for a JV cigarette factory with a production ceiling of 2.5 billion units, just like RJR and Rothmans." ${ }^{39}$ Further: "buying out an existing factory with large production capacity" was optional whereby "major reforms . . .may allow us to buy and operate inefficient factories."39 Any variation on the ideal situation was contemplated carefully. The CNTC continued to hold tight import quotas for foreign exchange, favouring foreign manufacturers with local production to equip their factories: "Direct licensing demands minimal investment and is relatively easier to get approval." 39 However, profitability to PM was the main concern. Continuing: "once CNTC is granted the license, the other options would be put on the shelf as CNTC has already got what it wants."39

TTC tactics to improve manufacturing arrangements paid off. In 1988 RJR established a \$21 million plant at Xiamen producing more than 2.5 billion cigarettes per year. In 1991 the first successful completion of PM's DIET plan came to fruition. In 1992 the CNTC promised to keep the transnationals on a short leash. However, after the TTCs instigated a year long investigation under section 301 of the US Trade Act combined with formally threatened retaliatory tariffs (\$3.9 billion US Chinese exports), all import licensing arrangements for China were dropped. China signed a Memorandum of Understanding with the US in $1992 .^{48}$ In August 1992 the second PM plant was established in Ningbo ${ }^{15}$ and in the same year Rothmans established themselves at Jinan. Local joint PM-CNTC Marlboro production for the domestic market commenced in 1994 and a new export brand Red and White was initiated in $1994^{49}$

In 1993 PM engaged an experienced Chinese consultant $\mathrm{Mr}$ Cheung Ching, previously used by Coca-Cola, to lobby for the Project Hope joint venture cut tobacco factory. "Mr Cheung has an impressive track record ... [he] does not come cheap. The deal will include $\$ 40000$ monthly expenses and a success fee of $\$ 4$ million. He will be given two years to get the job done." 39

As such expenditure indicates, PM was prepared to spend billions of dollars to realise their prize. In 1993 Michael Miles stated: “On the theory that part of our ability to attract attention/support will depend on how much we're willing to spend, we need to decide how much are we willing to spend. We need to look at some numbers before we decide, but we should be willing to at least think big. For example, Bill Webb mentioned while we were there that some thought had been given at some point to offering something in the billions for all or part of the CNTC ${ }^{\prime 50}$ indicating the pursuit of direct buy-out. Paul Lohr from RJR predicted that the CNTC would roll over in 1996-98: "James Kong envisions the local market loosening over the next 3 to 5 years with the eventual break up of CNTC." At the thought of this, RJR talked of a new China business strategy: "to pick up 2-3 billion units from several factories in a number of provinces." 51

Other non-tobacco transnationals with their eyes on China inspired the TTCs. In 1993 PM's Michael Miles cautioned: "That [News Corporation chief and PM board member Rupert] Murdoch and [General Electric's Jack] Welch both see huge potential in China doesn't "prove" it's there for us, but it certainly indicates that our sense of a truly huge opportunity is shared by some other very savvy international businessmen". ${ }^{50}$

\section{Part B: tobacco advertising in China}

"We believe that the universal appeal of the Marlboro Man and Marlboro Country transcends all flavor types." ${ }^{52}$

PM's Bill Webb rehearsed the industry's public position on its motivations regarding advertising, reiterating core statements of earlier documents like The Activities of Philip Morris in the Third World": "Advertising is critical to our ability to expand the geographical presence of our brands and sustain their premium image. ${ }^{54}$ Overall, the momentum of "aggressive promotional and merchandising activities" ${ }^{75}$ were thoroughly contemplated and used to maximise market share. Although publicly PM claimed these "early" markets were unaffected by advertising it was considered essential "to be delivering outstanding, well targeted advertising, primarily to build brand and advertising awareness and to provide the brand with an aspirational value that allows it to command a higher price." ${ }^{56}$ 
As in the West, the TTCs ran a public line on their declared position of not targeting nonsmokers, particularly women and children: "Although some advertisements appeal to young adults who smoke, American tobacco manufacturers do not target any advertisements towards children ... Moreover, research reveals that smoking initiation is a complex process, and advertising plays only a "miniscule" role_-"if any" - in that process." ${ }^{34}$ In 1982 the TTCs suggested that available evidence showed that their advertising was "not designed to attract new smokers of any age" 57 and that they were not seeking "to entice the non-smoking segment of Asian women to initiate smoking". ${ }^{34}$ It was argued that advertising served to: "introduce smokers to new tobacco products in the market, to encourage smokers to try the advertised product." ${ }^{\text {34 }}$

Other comments suggest a different perspective. The IRRC (Investor Responsibility Research Center Inc) report, 1982 suggested: "Little is known about the amounts spent by Philip Morris on cigarette ad campaigns or on the target groups these campaigns seek to influence". ${ }^{57}$ Claims that advertising only targeted existing smokers were weakened by a PM statement alluding to targeting young adult "starters" ${ }^{58}$ In PM interoffice correspondence, Cathy Leiber mentioned targeting young women with Virginia Slims in 1989 at a Pan Asia brand strategy meeting for Hong Kong and Asia. She argued: "we are naturally more interested to learn how you plan to target the emerging young adult female smokers rather than the older female smokers. ${ }^{59}$ In a five year marketing plan for 1981-85 involving China, Tso mentioned targeting segments "which are currently small but which may have long term development potential such as a female brand like Virginia Slims." ${ }^{60}$ Plainly, the TTCs were well aware of the huge potential to be gained by enticing the largely non-smoking segment of Chinese women into becoming smokers. Their principal tool in this endeavour was advertising: "Demographically, the population explosion in many underdeveloped countries ensures a large potential market for cigarettes. Culturally, demand may increase with the continuing emancipation of women and the linkage in the minds of many consumers of smoking manufactured cigarettes with modernisation, sophistication, wealth, and success-a connection encouraged by much of the advertising of cigarettes throughout the world." 58

The targeting of young males and young adult starters was mentioned more frequently. A 1991 PM meeting regarding the potential of the brand Parliament in the PRC submitted: "The potential consumers we are targeting at are male within the age bracket of 18 to 35, white collar, slightly more intellectual with at least secondary education, and in urban areas. Shanghai is chosen as a marketing base because Shanghainese consumers . . .are relatively more sophisticated by Chinese standards." "Parliament's imagery appeals to consumers' aspirations for upscale western life styles." ${ }^{31}$ Finally, developing brands to attract more subgroups, including the health conscious, was evidenced: "position a low numbers brand with appeal to smokers influenced by the smoking and health issue."

Significantly, in a 1989 brand awareness study conducted for PM by Walmsley Limited, 15-60 year olds in 1000 households were contacted to evaluate awareness of imported brands (43\% named an imported brand first) prompted awareness ( $85 \%$ named Marlboro first), and $85 \%$ reported smoking imported brands in the last three months. The receipt of imported cigarettes as gifts was likewise evaluated (53\% had received these as gifts in the last three months).$^{62}$ By including $15-18$ year olds in this research, we have explicit evidence of PM's interest in Chinese youth under 18 years old.

Different Chinese locations were clearly targeted. Depending on an initial manufacturing tie-up with a Chinese factory, in 1991 the aim was to position PM geographically in a way that would maximise market coverage and production capacity. "By establishing production facilities in northern, central, southern and western China, we would be positioned to serve the huge Chinese market effectively across all geographic regions."32 In PM's 1994 three year plan, six key markets were identified by urban population and income. These included Tianjin and Shanghai as fast growing and prosperous cities. Other potential markets included coastline cities and the industrial city of Chongoing in Sizhuan province. ${ }^{63}$

KEY MARKETING MESSAGES

Documents reveal aims to stimulate aspiration for an upmarket western or international lifestyle. Tailoring the Marlboro brand to fit the key Asian markets, questions were asked about the relevance of "Marlboro's communication" to Asian consumers and the ability of the brand to position itself: "consistent with user attitudes/lifestyles?" ${ }^{64}$ In 1990 younger, clean shaven cowboys were recommended where: "the older, gritty look does not have universal aspirational appeal." ${ }^{52}$ Marlboro was strongly marketed to Chinese consumers during a specific advertising and promotion strategy to "strengthen the young and modern image of the brand" and "add aspirational value by promoting its international image" ${ }^{64}$ In Hong Kong in 1983, the Americanisation of Winston television advertising was achieved by dropping the "Men of Hong Kong" campaign for a new campaign emphasising the "positively American" concept of the brand. ${ }^{65}$

In 1990 documents explicitly targeting Asian smokers proposed the use of a promotion technique called the "targeted group meeting point" (TGMP) by which promotional teams were dispatched to local hot spots with tobacco related samples and games in a brand awareness raising exercise. "TGMP is also an inexpensive way of collecting targeted smoker names for our database." ${ }^{52}$ In the Philip Morris Super Lights plan "special nightlife activities and shopping mall promotion" were mentioned. Such activities were used to "add fun 
and entertainment in the form of computer games for our consumers", ${ }^{66}$ including "touchscreen puzzles".

ADVERTISING BANNED

After the banning of direct product advertising in the print and electronic media in the PRC in 1992 the documents provide evidence of attempts to find loopholes to maintain product exposure. In 1993, PM cunningly employed indirect advertising for exposure using trademark advertising without product connotations "subject to approval governed by respective local rules and regulations of different provinces/cities." ${ }^{\text {67 }}$ Exposure was also maintained by "program sponsorships on TV (with entitlements such as program titling, opening/closing sequence, etc)". The TTC abuse of poorly scrutinised advertising restrictions in China has been a longstanding problem with a rise in TV infomercials, billboards, and sponsorship post $1992 .{ }^{6}$ The diversion of million dollar advertising budgets into loophole practices is a common TTC practice around the world and is particularly exploited in developing countries.

SPONSORSHIP

Sponsorship and promotional events were generally arranged to enhance the "heroic and import image" of international brands around "the key target group" ${ }^{52}$ of YAMS (young adult male smokers). ${ }^{68}$ The Marlboro Superbike Show in Taiwan in 1990 had a stated objective: "to strengthen Marlboro's brand image in relation with excitement, vitality and masculinity, especially among young adult consumers." ${ }^{\circ 9}$ In 1990: "The inaugural Marlboro dynasty cup are excellent examples of how we associate Marlboro with Asia's favourite sport and position Marlboro as the principal contributor to football development in Asia." ${ }^{52}$ A further PM concern was as to move away from "so-called "elitist sports" such as golf and tennis" to choose sports like soccer "supported by most Asian governments". ${ }^{69}$ Other than political motivations, sponsorship deals included targeted smoker sampling made explicit in 1990: "While sport is by far the best avenue to attract, sample, and influence our core target smokers, it's not the only way. International movies and videos also have tremendous appeal to our young adult consumers in Asia." 52

PHILANTHROPIC ACTIVITIES

Philanthropic activities in China were well documented as opportunities for PM corporate affairs to link the company with issues of social responsibility. In 1988 the development of a paramedical training program to service the handicapped was part of "a contribution to the China Welfare Fund for the Handicapped in the People's Republic of China." ${ }^{53}$ The explicit motivation behind such programmes was: "to counter attacks on tobacco sponsorship, we will continue to develop a comprehensive regional program of arts and sports sponsorship."70 Particular attention was to be paid to: "cultural projects and community service projects of national significance." Further: "We will utilise third parties . . .to identify and develop sponsorship opportunities and build ties with the sporting and cultural communities." ${ }^{70}$ It could be suggested that associations with sports and the health industry including ties with the Special Olympics in Hong Kong ${ }^{49}$ served dually to counter sponsorship attacks as well as form cliques with these groups, enabling a backdoor push for cooperation from health bodies. One document explicitly mentioned gaining access to the Ministry of Health to get a fair hearing "through our continuous support for the paramedical training program". ${ }^{70}$

\section{VOLUNTARY CODES FAVOURED}

As in the West, self regulating the marketing of cigarettes was used to avoid legislation as well as to portray industry responsibility. "If done honestly and with the concurrence of government authorities-and in advance of restrictive government proposals-industry codes can be accepted instead of legislation." ${ }^{25}$ RJR considered the utility of a voluntary code, to demonstrate that: "American tobacco manufacturers adhere to the advertising laws and regulations of the countries in which they operate." 36 John Dollisson alluded to the perverse motives of the TTCs in Asia: "A code may be beneficial but we must remember that we work in a competitive business environment and we are judged on our ability to increase volume and share. How do we combine/ reconcile these two issues?" ${ }^{29}$ However, Dollisson noted that the codes were useful to "effectively defend ourselves against criticisms based on lies or misconstruals", continuing: "If we could state a PM marketing policy indicating voluntary guidelines, it would be very beneficial. It could include: a clear policy stating we don't market to "minors" or non-smokers." ${ }^{29}$ The use of the code was again referenced by Matthew Winokur 1993: "The code puts PMI [Philip Morris International] on high ground regarding our marketing practices overseas, especially on the youth issue." The other USCEA members (B\&W and RJR) were subsequently encouraged to adopt such a document under the concern that: "Unless all three companies can be held to the same high standard, PMI's image will likely be reduced to that of the lowest common denominator."71

FLAWS IN TTC MARKETING

Other counter attacking strategies described in the documents reveal flaws in public statements endorsing the integrity of TTC cooperation and marketing. In anticipation of "a possible onslaught of coverage" at the 7th World Conference on Smoking or Health in Perth in April 1990, PM's Patrick Rekart warned: "please be aware of the following: . . .what is PM's sampling procedure in each market; and what kinds of activities do we do that could filter our products down to adolescents. Alternatively, what do we not do."72 Rekart referenced the "Jump Boy" principle, not applicable to Indonesia, since single stick sales are not allowed. Commenting in 1991 on 
PM's public relations efforts in regard to minors, Clive Turner admitted "Much of what we have done around the world has been desultory and patchy" with the real benefit in "being seen to cooperate on this particular issue" as "positive public relations and public affairs benefits". PM's work in relation to minors was evidently undertaken because it was "inexpensive to mount, and usually very difficult for the opposition effectively to counter without appearing sour and overcritical." 25

\section{Part C: smoking and health}

Here, the TTCs' objectives were plain: "Our objective is to limit the introduction and spread of smoking restrictions and maintain the widespread social acceptability of smoking in Asia."70 In a 1989 Hong Kong Tobacco Institute document it was stated: "Strengthen relations with China National Tobacco Corporation (CNTC) - to alert CNTC of the repercussions of anti-smoking sentiments generated under the influence of [Judith] Mackay and WHO" in order "to help the CNTC deal with allegations on smoking and health". ${ }^{73}$ As PM saw it, strengthening cooperation with the CNTC was a resource and expertise sharing exercise "to counter anti-smoking initiatives". ${ }^{24}$

The TTC's actions in China on the health debate were similar to those adopted in the West, including contracting Chinese health specialists for health research. In 1989 Patrick Rekart wrote of the need for: "A list of information/research needs so that we can "Asianize" our positions on the issues." "In the same year PM's John Dollisson noted: "On the health issue, we are assessing the literature on Asian populations looking for potential specialists. The comparisons between Asian and Caucasian populations present interesting positive evidence on the smoking and health controversy." ${ }^{44}$

USE OF INDEPENDENT SCIENTISTS

One example of efforts to heighten controversy was the ETS (environmental tobacco smoke) Consultants Project in Hong Kong. Hong Kong was one of the industry's four initial target markets for recruiting, educating, and orientating scientists in Asia. With the TTC promise in 1989 "To address the science of ETS and build a foundation of local data which can be used to put ETS in perspective", ${ }^{72}$ a network of "independent" Asian consultants was formed by US lawyer John Rupp based on an international trend of recruiting scientists who would run the industry line. The consultants were not tobacco experts $^{74}$ but rather people who the TTCs had predetermined would actively criticise the health lobby, undermine the smoking and health debate in China, and seek to bury ETS as an insignificant element in the wider context of indoor air pollution. Their political connections and personality attributes were paramount. Dr Linda C Koo from the department of community medicine, University of Hong Kong, described as having "an extremely attractive and sparkling personality" and being "utterly Americanized" was an attractive prospect. With her research focus being on oxides of nitrogen and respiratory disease, Dr Koo's expertise was of less importance than her comments on lung cancer in Chinese women: "Dr Koo believes [lung cancer] is principally caused by dietary factor (sic).... .Dr Koo talked of the "victimization" practised by the health lobby. In this environment, no one wants to stick their neck out, and no scientist will accept money from the tobacco industry." Speaking on the health lobby "Dr Koo informed us that Judith Mackay is now calling passive smoking "respiratory rape". What scientist wants to aid and abet rape?"74

Dr Sarah Liao from EHS Consultants Ltd, a close personal friend of Dr Linda Koo's and a specialist in asbestos, was another promising candidate: "Interestingly she is married to the postmaster general in Hong Kong and is presumably well connected politically ... She appears to have great integrity and objectivity as a scientist and criticises the health lobby for its inquisitorial tactics and scientific basis. Judith Mackay is not objective and not credible, according to Dr Liao. She also stated that TH Lam, who co-authored the COSH [Council on Smoking and Health] survey with Stuart Donnan is a "jerk". ${ }^{74}$

The same document shows that two ETS consultants were also recruited from China: Dr Fengsheng $\mathrm{He}$, director of occupational medicine, Chinese Academy of Preventative Medicine, Beijing, and Dr Guangguan Liu, chairman, department of air pollution control, Institute of Environmental Health and Engineering, Beijing.

\section{ASIAN STUDIES TO REFUTE THE WEST}

The TTCs held high hopes that in the large populations of Asia they would find anomalous data that could be used to cast doubt on claims about smoking causing disease. This was part of a global search for such data that had so far proved futile: PM's Jetson Lincoln, vice president of PM Planning, expressed his disappointment in one document discussing Chinese cancer clusters: "There is a great coincidence of smoking and longevity in a place in Ecuador but it turned out they didn't inhale." 75

Lincoln's memo discusses how to best obtain results required to disprove the causality theory: "the first essential is to learn the location of the lung cancer hot spot and the minimum distance one must go away from it to reach areas of average or below average lung cancer incidence." $75 \mathrm{He}$ continues: "Neither the Chinese tobacco people or ourselves should be dismayed if the prevalence of cigarette smoking in the high lung cancer areas should turn out to be above average. As a matter of fact I would expect it to be above average. As long as the disparity in lung cancer is greater than the disparity in cigarette consumption, we have a favourable result. An intermediate disparity in smoking rates in the high lung cancer area will merely testify that lung problems "cause" smoking."75 
By 1994, the researchers had produced results suggesting other hypotheses about the cause of lung cancer: "Hong Kong researchers say the food Chinese people eat, rather than the cigarette smoke they inhale, is the main cause of lung cancer. Dr Linda Koo and Professor John Ho have spent 14 years studying the cause of lung cancer among Chinese, say more vitamin $\mathrm{C}$ in the diet will dramatically reduce the rate of lung cancer."76

Hargrave of RJR gloated that: "The opponents of smoking in developing countries cannot produce anything like as sensational figures as those in developed countries relating to diseases and mortality rates which they allege to be causally connected with smoking. To date, therefore, the industry in developing countries has not been so severely indicted as the major factor in this threat to public health." 77

In 1991 Clive Turner threw out a further decoy to counter the causal hypothesis and redirect political attention away from children smoking. "The visible dust and generally disgusting airborne pollution must unquestionably be THE prime culprit." Turner continued "It is THIS widespread and real problem to which the government should direct its attention and forget the utterly minor matter of smoking by very young children in Hong Kong." 78

By 1993-95 there was talk of the great benefit of the growing number of studies conducted in developing and Asian countries, that rebut conclusions from western countries, as well as from Asian scientists citing these findings at conferences and in the media. ${ }^{24}$ Symposia were held to disseminate these results in Asian countries. ${ }^{24}$ Further workshops were encouraged by Walk as late as 1996: "to bring together the key epidemiologists on environmental issues in China to discuss quality criteria for research to be used in risk assessment of potential hazards and in particular so-called "weak associations" in China."79

THE OPIUM WAR

The TTCs were outraged over tobacco control advocates relating the historical Chinese Opium War with the spread of tobacco in China: "attempts to link cigarette market opening to the Opium War are strained and without historical foundation. The Opium War originated because the British had introduced opium from their colonies into China and continued to force-feed it into China despite the objections of the Chinese imperial government." Charging the Chinese with responsibility: "Over 100 years before the Opium War, China was already exporting tobacco to Macao and the Philippines for shipment to Spain, Portugal, and other parts of Europe." ${ }^{34}$ They also objected to talk of tobacco being a drug: "The equating of tobacco and narcotics trivialises the serious drug problem that society now faces." 34

COUNTERACTING THE ANTI-TOBACCO MOVEMENT To ensure that TTC views prevailed in Hong Kong government decision making it was con- sidered vital to develop negotiation points with government, "monitor all aspects of government's legislative programme". ${ }^{80}$ Such monitoring included development of a "war book" on future and present decision makers. Methods to best direct political messages to the press and electronic media were also recommended.$^{80}$ After watering down $\mathrm{COSH}$ proposals, the Tobacco Institute stated in 1989, that: "PM will develop and implement a legislative "early warning" system throughout the region to provide the earliest possible notice of government action to restrict our business." 72 A broad two point TTC strategy was outlined as: "(1) To defend the industry as vigorously as possible. This would include opposing and resisting the government's activity on both principle and for practical purposes. (2) To negotiate and remain available to consult with the government to achieve compromises wherever possible" ${ }^{81}$

In 1991 Ray Donnner (RJR for Asia Pacific office Hong Kong), Clive Turner, (managing director of the Asian Tobacco Council), and Bob Fletcher (Rothmans), presumably all representing the Asian Tobacco Council, met with CNTC vice president, $\mathrm{Mr}$ Jin Maoxian and three of his staff about smoking and health and tobacco control activists in China. The TTCs showed Mr Jin news clippings, largely quoting Dr Judith Mackay, to show "what the anti-smoking activists are saying about China outside China". ${ }^{82}$ Likewise Mr Jin conveyed the CNTC's opinion on smoking and health to the TTCs: "(1) Smoking is an accepted custom, and although it can have certain effects on health of smokers, it is not agreed that smoking definitely causes lung cancer. According to the HM [Health Ministry], 50\% of lung cancer deaths are caused by smoking, but, of 100000 people who smoke, how many actually die from lung cancer? (2) The smoking rate among CNTC employees is quite high, but the percentage of people working in the Shanghai cigarette factory who develop lung cancer is smaller than the percentage who do of Shanghai's total population ... Smoking is not like taking drugs in terms of danger." ${ }^{\prime 2}$

$\mathrm{Mr}$ Jin continued: "China is a socialist country ...there is a certain amount of cooperation between the CNTC and the HM . . . They commented that only in China could tobacco and health people sit down together in harmony and discuss issues." "It is CNTC's position to cooperate with the HM and "produce less harmful products". CNTC regards the HM people as doing their duty, but also does not wish them to be excessive or unscientific." ${ }^{82}$ Evidently, the CNTC, as the world's largest tobacco producer, had an approach to the smoking and health debate that was far more frank than the TTCs', admitting causality and working with the health ministry to minimise harmful components of cigarettes.

In seeking to unify the tobacco frontier against the antis and get the CNTC on side through the meeting, Ray Donner and Clive Turner did not want to push too far: "They should be given some time to digest what has 
already been given them so as not to be given the impression they are being rushed or pressured. ${ }^{\prime 22}$

HONG KONG'S POLITICAL POWER

Clive Turner was evidently frustrated in having to deal with the Hong Kong government: "They do have enormous political power in Hong Kong, and can virtually do as they please - and they often do ... There is a degree of arrogance and no small amount of patronising apparent, and I for one find it disagreeable to observe." 27 Turner suggested that with 1997 approaching "the truly heavyweight work with China is done in London by [Douglas] Hurd and his men" 27 and called for PM: "to come forth with ideas about how the Tobacco Institute (Hong Kong) could usefully bring some back door pressure to bear through London." 27

In 1989 the Asian Tobacco Council Charter called for strategic regional collaboration between the TTCs to "monitor regional anti-smoking groups" and "develop and coordinate regional action plans to address anti-smoking initiatives". ${ }^{83}$ Such collaborative networks enabled the prompt communication of anti-tobacco information for pre-empting or counteracting their action. Focused questioning of the opposition's priorities, targets, and thinking was undertaken to redirect and strengthen the TTC's pro-activity in Asia and "to balance the unremitting and emotionally geared anti-tobacco crusading". ${ }^{25}$ From there, garnering support for the industry position ${ }^{80}$ included marketing decided messages "with an intensity and level of emotion that equals that of the other side". ${ }^{84}$ "We are making every effort to get our story told." $"{ }^{\prime 85}$

The TTCs carefully considered tobacco control proposals by the industry regulation they imposed. In Hong Kong in 1976, John Thompson of RJR recommended "a T\&N [tar and nicotine] numbers league" which "would upset the government and involve them in setting up controls, laboratories, standards, etc" was contemplated against "a concerted no smoking campaign" possibly causing a "damping down consumption" and "restructuring towards milds". ${ }^{86}$ In 1980 in Hong Kong, Blackmear was discussing how: "local government might be dissuaded from undertaking a $T \& N$ reporting program if they are made aware of all the administrative and technical requirements of such a program." RJR then enlisted assistance for: "the development of a comprehensive listing of all these requirements, eg, test equipment requirements, scientific controls, printing costs, etc." ${ }^{87}$

Ten years later in 1991 they were still singing a familiar tune: "Given the difficulties of today's challenges to Customs and Excise for controlling contraband cigarettes which can be identified with a glance, how can the government hope to control excessive "tar" cigarettes which require a sophisticated laboratory to identify?" 88

Tobacco control advocates were painted as a highly irrational, emotionally motivated group aiming at easy targets: "tobacco export industry as a whole, and cigarette exporting in particular, is under attack by anti-smoking groups that use their time in public forums to denounce what they call "export of death"." 84 In 1989 proposals from Hong Kong's COSH were labelled "manipulative" to society, guilty of "over-stressing of government's role in society" and lacking in "balance and accuracy" ${ }^{89}$

Clive Turner of the Hong Kong Tobacco Council made a particularly florid speech in 1990 to colleagues at the sixth world tobacco exhibition and symposium. "I have always hoped that such people, seized as they are with their hatred of tobacco, are occasionally haunted by the fear that somewhere in the world there may lurk a happy and unworried smoker raising the proverbial and graphic two fingers at them." 90 His speech argued that tobacco control advocates were engaged in a "ritual of purification". "It is almost as if they are conducting an evangelical crusade, and nothing short of the end of the world will cause a shift in direction." ${ }^{90} \mathrm{He}$ continued: "I call them "shower adjusters". They would enjoy adjusting your shower temperature for you if they could get access, just knowing exactly what is right for you - and for all mankind. Interestingly, they seldom create employment or wealth." "They were not the sort of folk with whom you would feel at ease having a chat over a drink! Tense, with no sense of humour, wound up, and consumed by their passion." ${ }^{91}$ "Extremism is part of their way of life, and runs rampant throughout the anti-tobacco movement." 90 And to finish: "Our detractors will not allow the use of the word "debate"'. They claim the debate is all over, and that all which remains to be done is to eliminate tobacco across the world." ${ }^{90}$

\section{Postscript}

Recently, it was discovered that President Clinton's Trade Representatives were secretly pressuring China into accepting American cigarettes and tobacco as a condition of America's support for China's entry into the World Trade Organisation. The agreement, awaiting a congressional vote this summer, would bring millions of dollars to the US tobacco companies, liberalising trade instead of a year by year renewal of trade concessions. For cigarettes, the current tariff of $65 \%$ would fall in equal installments to $25 \%$ by 2004 . Opening the Chinese market to investment would enable Philip Morris to build manufacturing plants using mainly Asian tobacco. The US Trade Representative's office said its mission was to level the playing field, not promote health and social policy. ${ }^{91}$

1 Dobson RP. China cycle, 1946. In: Cochran S. Big business in China: Sino-foreign rivalry in the cigarette industry, 1890 1930. Harvard University Press, 1980.

2 Cochran S. Big business in China: Sino-foreign rivalry in the cigarette industry, 1890-1930. Harvard University Press, 1980.

3 Tennant. Cigarette and tobacco trade in China. Chinese Economic Bulletin 225 (June 13, 1925), p338. SC p 202, ref 3, table on $\mathrm{p} 234$

4 The World Bank Development Economics Central Database. China at a glance 1997. http://www.worldbank.org/ html

5 Chinese Academy of Preventative Medicine, Chinese Academy of Preventative Medicine, Chinese Association of 
Smoking and Health, Department of Disease Control, Ministry of Health, PR China, and Office of the Committee of the National Patriotic Health Campaign. Smoking and health in China 1996. National prevalence survey of smoking patterns. Beijing: China Science and Technology

6 World Health Organisation. Tobacco or health: a global status report. Geneva: WHO, 1997

7 Sun JP. International consultation on tobacco and youth, Singapore, 28-30 September 1999.

8 Peto R, Chen Z, Boreham J. Tobacco-the growing epidemic in China. FAMA 1996;275:1683-4.

9 Gembler A. Confidential note to the files. Re: China 10 November 1977 PM1000274344 4. July 1999.

10 Campbell W. 10 September 1979 PM1000219807.

11 Frankel G, Mufson S. Big Tobacco's global reach: vast China market key to smoking disputes. The Washington Post, 20 November 1996. http://www.washingtonpost.com/ Post, 20 November 1996. http://www.w

12 1981-1985 Five year plan - marketing planning PM2504011909.

13 Nelson J, Storr H. Remarks by Hans G. Storr at prudential securities consumer conference 8 September 1993 Boston, Massachusetts (to be followed separately by remark from Jack Nelson) 8 September 1993 PM2501109020.

14 PM Asia Incorporated PRC Market briefing April 1994 PM20457563

15 Bible GC. Philip Morris International 1993 (Williamsburg) Plan Presentation 28 April 1993 PM2500065672.

16 Anon. Exporting tobacco addiction. Lancet 1998;351:1571.

17 Minutes of Pasquine's meeting Tuesday 6 March 1984 (minutes on China reported by O'Brien P, Vaughan J) 6 March 1984 PM2000573127.

18 The Shenzhen factory May 1985 PM2000510256.

19 Bass L. Inter-office memorandum. Weekly highlights process technology \& development 22 March 1984 process techno

20 Mansfield CT. Trip report world tobacco exhibition and conference Hong Kong 3-5 December 1985 RJR504905036.

21 Report on Hong Kong meeting with Jack Gibson and George Cheung, PM February 1985 PM2023799600.

22 PM International business 1989-1993 plan March 1989 PM2500103013.

23 Caplis P. CNTC visitors inter-office correspondence 23 May 1989 PM2500089866.

24 Philip Morris Asia/Pacific 3 year plan 1993-1995 December 1992 PM20501824318.

25 Turner ADC. November public affairs conference: Hong Kong: 19 November (provisional date) 13 June 1991 PM2504002954

26 Burrell W. US/ROC trade policy Philip Morris International inter-office correspondence 19 October 1992 PM2500052526.

27 Turner ADC. 4 April 1991 PM2504003000.

28 Philip Morris Asia Inc 1985-1988 three year plan preliminary review September 1985 PM2504011941.

29 Dollison (sic) J. Minutes from Thursday June 21 presentations marketing restrictions 21 June 1990 tions marketing

30 Webb W. 1989 PMI board presentation - Asia/Australia 29 August 1989 PM2500089009.

31 People's Republic of China 1991 PM2500098237.

32 Notes on international \& regulatory issues from a variety of sources [subheading]: China Daily (Business Weekly) 6/12 December 1992 PM2025600328.

33 Buddle C. Judge blasts tobacco firms as Jerry Liu sentenced. South China Morning Post, June 251998.

34 USCEA. Global tobacco trade, US policy and American cigarettes. Executive summary 4 January 1996 RJR507610680.

35 Dyer J. Kennedy export hearings 4 May 1990 PM2024258710.

36 Washington Jones $M$. External relations taskforce comments. "Perceived Dichotomy" 1992 RJR512546390.

37 USCEA. US trade policy regarding tobacco exports May 1994 PM2 045756222.

38 Burson-Marstellar (sic). Joint enterprise for trade 14 March 1990 PM2500079292.

39 China - vision $2000+1993$ PM2504033326.

40 Fuller C China/USTR Inter-office correspondence 9 August 1993 PM2046988364.

41 Barnes PL, Chan D. 1994 original budget opening remarks, PL Barnes. 11 October 1993 PM2504043190.

42 Webb W. Luncheon briefing materials-Madame Wu Yi, PRC Minister of Foreign Trade and Economic Cooperation inter-office correspondence 18 April 1994 PM2046988175.

43 Speaking points - private meeting with Minister Wu, 19 April 1994 PM2045756321.

44 Dollison (sic) J. 1989 2nd revised forecast presentationcorporate affairs 15 June 1989 PM2500101311.

45 [Sub heading]: Items for consideration relating to PMCNTC long-term cooperation July 1993 PM2053383133.
46 CORESTA. Cooperation Centre for Scientific Research Relative to Tobacco June 1991 PM2029172132.

47 Xun X. China national tobacco corporation. The sixth world tobacco exhibition \& symposium 22-25 October 1990 RJR511970074.

48 Mackay J. Smoking in China: "the limits of space". Tobacco Control 1997;6:77-9.

49 Dunbar L. Philip Morris International Inc presentation to PRC journalists, 21 August 1995 PM2046882750.

50 Miles $M$. China inter-office correspondence 3 November 1993 PM2046988206.

51 Lohr P. RJ Reynolds tobacco international inc. research and development Winston-Salem NC 2710517 December 1993 RJR516413378.

52 Marlboro 1990 PM2504034844.

53 Philip Morris International. The activities of Philip Morris in the third world April 1988 PM2024261707.

54 Webb W. 1993 board presentation-closing 19 October 1993 PM2500157095.

55 Hong Kong mission statement 1980 RJR500351839-1863.

56 Marlboro creative brief 1993 PM2504000588.

57 IRRC proxy issues report tobacco sales in developing countries 7 April 1982 RJR503653426.

58 To J. Weekly meeting minutes of April 26, 1993 inter-office correspondence 3 May 1993 PM2504018515.

59 Leiber C. Philip Morris Asia inter-office correspondence 25 October 1989 PM2504034812 13.

60 Tso D. 1981-1985 five year plan-Marketing planning inter-office correspondence 25 September 1980 PM2504011906.

61 Parliament in the People's Republic of China (Tokyo meeting May 1991) May 1991 PM2504053797.

62 Walmsley Limited. China consumer series: 1989 cigarette section: Shanghai September 1989 PM2504034565.

63 Cheung G. China 3YP 1994-1996 1994 PM2504033297.

64 WPP Group Marlboro branding and positioning audit 1991 PM2504010284.

65 Knouse P. Winston advertising in Hong Kong 14 March 1983 RJR503405707.

66 Philip Morris Super lights-looking ahead 1991 PM2504018360.

67 Wilson W. F-1 and GP bike evaluation inter-office correspondence 12 May 1993 PM2504052843.

68 Soccer sponsorship 24 February 1994 PM2504051355A.

69 da Roza E Inter-office correspondence Marlboro Superbike Show '90 18 September 1990 PM2504016566.

70 PM Asia Philip Morris Asia Corporate Affairs Plan 1990-1992 December 1989 PM2500084000.

71 Winokur M. PMI marketing code communications plan Inter-office correspondence 25 March 1993 PM2045680295.

72 Rekart P Corporate affairs meeting Inter-office correspondence 18 December 1989 PM2504042075.

73 Propose HKTI work objectives for 198917 February 1989 PM2504002841.

74 So S Asia ETS consultants project 25 February 1989 PM2500048655.

75 Lincoln J 24 November 1980 PM2024258054.

76 RJRTI. Public Relations News Report 28 June 1994 RJR516413337.

77 Hargrove G. RJR502122633.

78 Turner ADC. Department of community medicine report: studies on respiratory health in Hong Kong 23 July 1991 PM2504002962.

79 Walk R Support of good science in Asia Inter-office correspondence 4 October 1996 PM2060565640.

80 JMA. Tobacco institute of Hong Kong strategic plan for 1990 April 1990 PM2504002900.

81 RJR502121909.

82 Turner ADC Donner R Meeting with CNTC 25 June 1991 PM2021546773.

83 PMAI. Philip Morris Asia Inc; Tobacco Exporter Asian Tobacco Council (ATC) basic charter December 1989 PM2504042080.

84 Burson Marsteller Joint enterprise for trade 14 March 1990 PM2500079292.

85 Miles M, Murray W, Storr H. Remarks by senior executives 1994 Annual meeting of the stockholders Philip Morris Companies Inc. 21 April 1994 PM2500122743.

86 Thompson JA. Smoking and health-Hong Kong 3 December 1976 RJR500539688.

87 Blackmear M. Inter-office memorandum 25 March 1980 RJR500882137.

88 Scarritt J Smoking (Public Health) (Amendment) Bill 1991 5 November 1991 PM2504064327.

89 Chow B March 1989 PM2504064362.

90 Turner C The sixth world tobacco exhibition \& symposium 22-25 October 1990 RJR511970081-0100.

91 Hall J. Trade deal helps leaf firms: China has agreed to cut tariffs on US cigarettes as well as leaf tobacco. Media General News Service. Richmond Times-Dispatch, 19 March 2000. from Global-link: gt-int@globalink.org 